\title{
PENGEMBANGAN LEMBAR KERJA PESERTA DIDIK ELEKTRONIK BERBASIS FLIPBOOK PADA MATA PELAJARAN EKONOMI KELAS XI
}

\author{
Virda Fithrotun Nufus ${ }^{1}$, Norida Canda Sakti ${ }^{2}$ \\ Pendidikan Ekonomi, Universitas Negeri Surabaya \\ Email: virdafnufus@gmail.com, noridacanda@unesa.ac.id
}

Website : https://jurnal.uin-antasari.ac.id/index.php/ptkpend/index

Received: 22 April 2021; Accepted: 02 Juni 2021; Published: 14 Juni 2021

\begin{abstract}
This research to develop an electronic Student Worksheet using a flipbook and describe the feasibility, practicality, and effectiveness of its use. Thiagarajan's 4D development model, includes defining, designing, developing, and deploying. The subjects of the research trial were 20 students of class XI MIA 6 SMAN 2 Lamongan. The results obtained that the flipbook-based electronic Student Worksheet is feasible, practical, and effective to be used as teaching material with the acquisition of product feasibility $81.45 \%$ very feasible, product practicality through student responses of $95 \%$ very feasible, effectiveness with a percentage of complete results study by $80 \%$.
\end{abstract}

Keywords: Flipbook; Student Worksheet; Economics

\begin{abstract}
ABSTRAK
Penelitian ini bertujuan untuk mengembangkan Lembar Kerja Peserta Didik elektronik dengan menggunakan flipbook dan mendeskripsikan kelayakan, kepraktisan, dan keefektifan penggunaannya. Model pengembangan 4D dari Thiagarajan, meliputi pendefinisian, perancangan, pengembangan, dan penyebaran. Subjek uji coba penelitian merupakan peserta didik kelas XI MIA 6 SMAN 2 Lamongan sebanyak 20 orang. Hasil penelitian diperoleh bahwa Lembar Kerja Peserta Didik elektronik berbasis flipbook layak, praktis, dan efektif untuk digunakan sebagai bahan ajar dengan perolehan kelayakan produk $81,45 \%$ sangat layak, kepraktisan produk melalui respon peserta didik sebesar 95\% sangat layak, keefektifan dengan presentase ketuntasan hasil belajar sebesar $80 \%$.
\end{abstract}

Kata Kunci: Flipbook; Lembar Kerja Peserta Didik; Ekonomi

\section{PENDAHULUAN}

Seiring berkembangnya kemajuan teknologi dan informasi dapat membantu kegiatan belajar mengajar di dunia pendidikan. Dengan adanya kemajuan teknologi menuntut guru mengembangkan potensinya di bidang teknologi dan informasi untuk diterapkan pada proses pembelajaran. Guru sebagai fasilitator bagi peserta didik untuk memberikan gambaran bahwa peserta didik diharuskan berperan aktif mencari dan mengelola sumber informasi pengetahuan tersebut agar peserta didik mampu membangun pengetahuannya sendiri (Sulastri \& Hakim, 2014). Oleh sebab itu dibutuhkan suatu pembaruan dalam kegiatan belajar mengajar. Salah satunya yaitu inovasi bahan ajar digital yang menjadi salah satu kesempatan dalam menjawab tuntutan di era global saat ini. Dalam masa pembelajaran daring seperti yang ada pada saat masa pandemi ini juga membutuhkan bahan ajar digital untuk menunjang kegiatan belajar mengajar berlangsung. Salah satu jenis dari bahan ajar adalah lembar kerja peserta didik yang dibentuk dalam format elektronik. Lembar kerja peserta didik elektronik diterbitkan 
dengan format digital yang terdapat gambar serta tulisan dan dapat dibaca menggunakan perangkat elektronik seperti komputer dan smartphone (Yulaika et al., 2020).

Berdasarkan hasil dari observasi di SMAN 2 Lamongan, bahwa terdapat dua kelas XI IIS dan tiga kelas XI MIA yang mendapat mata pelajaran ekonomi. Kelas XI MIA 6 merupakan kelas dengan nilai PTS pelajaran ekonomi paling rendah yaitu sebesar 67,5 disisi lain nilai Ketuntasan Belajar Minimal (KBM) sekolah yakni 80 dan karakteristik peserta didik kelas XI MIA 6 merupakan peserta didik yang dominan lebih menyukai proses pembelajaran yang menggunakan teknologi atau smartphone. Oleh sebab itu kelas XI MIA 6 ditunjuk peneliti untuk kelas ujicoba dengan 20 peserta didik..

Selain itu, hasil yang didapatkan melalui wawancara dengan guru ekonomi kelas XI mengemukakan bahwa kegiatan belajar mengajar didominasi menggunakan Lembar Kerja Peserta Didik konvensional yang telah disediakan sekolah. Dimana LKPD konvensional ini bersifat naratif atau berisi uraian yang kurang dalam menunjang keaktifan peserta didik pada kegiatan belajar. Selain itu desain LKPD konvensional umumnya kurang dalam menekankan berbagai warna dan gambar sehingga terlihat monoton. Hal tersebut bisa mengakibatkan peserta didik sulit dalam pemahaman materi dan dapat menyebabkan rasa bosan muncul pada saat kegiatan belajar mengajar.

Salah satu materi yang substansinya cenderung berubah mengikuti Undang-undang yang berlaku adalah materi APBN dan APBD pada Kompetensi Dasar (KD) Menganalisis APBN dan APBD dalam pembangunan ekonomi. Materi ini banyak membuat peserta didik kesulitan dikarenakan banyaknya komponen-komponen yang terdapat dalam APBN dan APBD, serta komponennya yang cenderung berubah mengikuti Undang-undang yang berlaku sedangkan buku teks yang digunakan oleh sekolah cenderung terlambat mengikuti perkembangan. Sehingga sehingga dalam proses pembelajaran guru perlu menyusun Lembar Kerja Peserta Didik (LKPD) sebagai bahan ajar.

Dalam LKPD elektronik berbasis flipbook ini memberikan inovasi dalam bentuk interaktif yang terdapat audio, gambar, dan video. Selain itu flipbook mudah digunakan dimana saja dan bersifat paperless. LKPD elektronik juga mendukung kegiatan pembelajaran daring pada kondisi pandemi sekarang. Karena LKPD elektronik dapat mudah dimiliki oleh peserta didik hanya dengan dibagikan (share) misalnya melalui sosial media seperti WhatsApp, Telegram, Line, dan Facebook.

Berdasarkan uraian permasalahan di atas, maka diperlukan sebuah inovasi dalam sebuah LKPD yang inovatif dan menarik serta dapat menumbuhkan keaktifan peserta didik pada proses pembelajaran serta diharapkan hasil belajar mengalami kenaikan agar memenuhi Kriteria Belajar Minimal (KBM) sekolah. Dari hasil telaah tersebut, peneliti menentukan pengembangan Lembar Kerja Peserta Didik elektronik berbasis flipbook.

Menurut (Saputri et al., 2019) Lembar Kerja Peserta Didik adalah bahan ajar yang salah satunya bisa dilakukan pengembangan oleh seorang guru sebagai fasilitator dalam proses pembelajara. Lembar Kerja Peserta Didik yang dirumuskan bisa didesain dan dikembangkan selaras dengan keadaan serta situasi kegiatan pembelajaran daring yang dihadapi pada saat ini. Sedangkan Lembar Kerja Peserta Didik Elektronik merupakan jenis dari bahan ajar yang didesain dalam melakukan kegiatan belajar mengajar luring maupun daring yang dikemas dalam format digital sehingga dapat membuat pembelajaran lebih bersifat interaktif (Yulaika et al., 2020). Berdasarkan ulasan pengertian di atas bisa diringkas bahwa Lembar Kerja 
Peserta Didik Elektronik adalah jenis bahan ajar yang bisa dilakukan pengembangan oleh guru sebagai fasilitator dan dikemas dalam format digital sehingga dapat membuat pembelajaran bersifat interaktif.

Salah satu perangkat lunak yang dapat membuat tampilan Lembar Kerja Peserta Didik elektronik lebih interaktif dan menarik yaitu Flip PDF. Aplikasi Flip $P D F$ merupakan suatu software yang sesuai digunakan sebagai media pembelajaran dimana aplikasi ini terdapat beraneka ragam fitur seperti gambar, video, serta audio yang bisa mennghasilkan media pembelajaran interaktif sehingga mampu menumbuhkan minat peserta didik dalam proses pembelajaran (Fitri, 2020).

Kelebihan yang dimiliki flipbook ini antara lain yaitu adanya fitur hyperlink, gambar yang menarik, audio, video dan efek flip yang dapat membuka atau membalik buku sehingga seperti membaca sungguhan (Asmi et al., 2018). Selain itu aplikasi Flip $P D F$ ini sangat mudah digunakan dan produk yang dihasilkan bentuk SWF atau Flash, HTML untuk di publikasikan melalui website.

Penelitian terdahulu oleh Awalsyah dkk (2018) menjelaskan bahwa pengembangan lembar kerja siswa berbantuan Kvisoft Flipbook Maker dinyatakan valid. E-modul berbasis flipbook mendapatkan penilaian positif dikarenakan materi pembelajaran sangat mudah dipahami oleh peserta didik, pengoperasian sangat mudah, unsur musik dan animasi dinilai dapat meningkatkan motivasi, minat, dan hasil belajar peserta didik. Penelitian lain oleh Riyanto dkk (2020) menyatakan bahwa penggunaan bahan ajar yang inovatif membantu siswa lebih termotivasi dalam proses pembelajaran karena era digital baru di pendidikan. Berdasarkan penelitian terdahulu di atas, bisa disimpulkan bahwa flipbook dapat meningkatkan motivasi, minat dan hasil belajar peserta didik dalam proses pembelajaran.
Dari uraian latar belakang di atas, peneliti memiliki tujuan untuk mendeskripsikan kelayakan, kepraktisan, dan keefektifan Lembar Kerja Peserta Didik elektronik berbasis flipbook pada mata pelajaran ekonomi kelas XI.

\section{METODE PENELITIAN}

Jenis penelitian ini adalah penelitian dan pengembangan atau R\&D. Model pengembangan yang digunakan yaitu pengembangan 4D dari Thiagarajan yang meliputi 4 tahapan yaitu pendefinisian, perancangan, pengembangan, dan penyebaran. Tahap penyebaran tidak dilaksanakan karena penelitian ini bertujuan sebatas memperoleh prototype LKPD pada mata pelajaran ekonomi.

Penelitian ini menggunakan desain ujicoba One Group Pretest-Postest Design. Untuk mengaplikasikannya yaitu melakukan pretest kepada peserta didik sebelum diberi tindakan, setelah itu memberikan posttest setelah ada tindakan.

Subjek ujicoba penelitian yaitu kelas XI MIA 6 SMAN 2 Lamongan yang berjumlah sebanyak 20 orang yang bisa menggambarkan individual populasi. Untuk mendapatkan sampel dilakukan secara random dalam penelitian ujicoba terbatas.

Instrumen pengumpulan data yakni berbentuk data kualitatif dan data kuantitatif. Dalam mendapatkan data kualitatif dapat dilakukan dengan lembar telah yang berbentuk saran dan komentar para ahli untuk menyunting LKPD. Selanjutnya dalam mendapatkan data kuantitatif melalui lembar validasi, angket respon peserta didik, dan soal pretest dan posttest.

Teknik analisis data validasi dan respon peserta didik menerapkan kriteria interpretasi skor skala likert. Hal itu bisa diketahui di tabel bawah ini:

Tabel 1. Kriteria Interpretasi Skor

\begin{tabular}{ll}
\hline Skor & Kriteria \\
\hline $81 \%-100 \%$ & Sangat Layak \\
$61 \%-80 \%$ & Layak
\end{tabular}


Jurnal PTK dan Pendidikan

Vol. 7, No. 1, Januari - Juni 2021 (27-35)

\begin{tabular}{cc}
$41 \%-60 \%$ & Cukup Layak \\
$21 \%-40 \%$ & Tidak Layak \\
$0 \%-20 \%$ & Sangat Tidak Layak \\
\hline \multicolumn{2}{c}{ Sumber: (Riduwan, 2018) }
\end{tabular}

Berdasarkan teknik analisis data hasil belajar peserta didik, peneliti menerapkan kriteria ketuntasan klasikal seperti di bawah ini:

Tabel 2. Kriteria Ketuntasan Klasikal

\begin{tabular}{ll}
\hline Presentase & Kriteria Interpretasi \\
\hline$<75 \%$ & Tidak Tuntas \\
$\geq 75 \%$ & Tuntas \\
\hline
\end{tabular}

\section{HASIL DAN PEMBAHASAN}

Penelitian ini akan menghasilkan Lembar Kerja Peserta Didik elektronik berbasis flipbook dengan penerapan model pengembangan 4D oleh Thiagarajan. Tahap awal adalah pendefinisian (define): a) analisis awal yaitu memperhatikan kurikulum yang dipakai oleh sekolah. Kurikulum yang diterapkan di SMAN 2 Lamongan yakni kurikulum 2013. Selain itu analisis awal diketahui bahwa pemahaman peserta didik pada materi APBN dan APBD masih rendah dibuktikan oleh hasil belajar 18 peserta didik belum memenuhi kriteria ketuntasan belajar minimal (KBM), b) analisis peserta didik dilaksanakan kepada peserta didik kelas XI MIA 6 SMAN 2 Lamongan. Kelas XI MIA 6 dipilih karena peserta didik kelas tersebut lebih menyukai pembelajaran yang memanfaatkan teknologi, c) analisis tugas dilakukan karena rendahnya nilai pada materi APBN dan APBD disebabkan oleh adanya banyak istilah yang kurang dipahami. Peserta didik cenderung menghafal tanpa mengerti dan memahami materi tersebut. Selain itu, juga dimungkinkan karena kurangnya kemampuan dalam menghubungkan antara teori atau permasalahan di kehidupan nyata yang menyebabkan peserta didik kesulitan memahami materi pembelajaran, d) analisis konsep yaitu memakai KD 3.6 yaitu APBN dan APBD dalam pembangunan ekonomi, e) analisis tujuan untuk mengatasi permasalahan tersebut yaitu bahan ajar yang akan dikembangkan nantinya memuat penjelasan materi pemahaman lebih rinci serta pemberian contoh autentik antara permasalahan atau teori dengan penerapan melalui kehidupan nyata pada indikatorindikator yang menjadi fokus utama. Dengan demikian diharapkan peserta didik mampu memahami materi APBN dan APBD yang memiliki nilai terendah sebagaiman dijelaskan pada tahap analisis

Tahap kedua yaitu perancangan (design) dimana Lembar Kerja Peserta Didik yang dirancang secara elektronik berupa flipbook dengan memanfaatkan smartphone untuk mengoperasikannya, karena diketahui bahwa seluruh peserta didik telah memiliki dan terbiasa menggunakannya. Kelebihan Lembar Kerja Peserta Didik elektronik flipbook dibandingkan dengan konvensional yaitu nantinya Lembar Kerja Peserta Didik bersifat produk paperless sehingga mudah digunakan dimana saja. Terdapat berbagai fitur yang menarik minat peserta didik untuk belajar seperti adanya audio, video dan gambar. Flipbook ini mudah dibagikan melalui sosial media seperti Whatsapp, Telegram, Line. Dalam materi APBN dan APBD di Flipbook ini nantinya menghubungkan antara teori atau permasalahan di kehidupan nyata dengan materi agar dapat meningkatkan pemahaman peserta didik dengan penyajian yang interaktif. Berikut tahapan (design): a) perumusan tes dimana peneliti melakukan pembuatan pretest dan posttest dengan soal pilihan ganda, b) perancangan terhadap LKPD elektronik dimulai dengan mendesain sampul depan LKPD dengan menggunakan corel draw dan menyusun materi APBN dan APBD, c) Setelah pembentukan LKPD selesai tahap selanjutnya yaitu menjadikan semua file satu dalam format PDF, d) pemilihan software, yaitu mengaplikasikan software flip PDF yang dibuat secara offline dan menyajikan beraneka macam fitur yang menarik serta mudah dikreasikan sesuai dengan kreativitas, e) penentuan format 
LKPD elektronik ini adalah SWF atau flash yang dipublikasikan di website.

Tahap ketiga yaitu pengembangan (develop), hasil dari rancangan awal LKPD elektronik yang sedia disusun selanjutnya ditelaah oleh dosen ahli materi dari Pendidikan Ekonomi, ahli media dari dosen Teknologi Pendidikan, dan ahli evaluasi dari dosen Pendidikan Ekonomi. Setelah itu peneliti menyempurnakan media flipbook yang sesuai komentar dan saran yant sudah diberikan oleh para ahli. Berikut yaitu beberapa penyempurnaan dari LKPD elektronik:

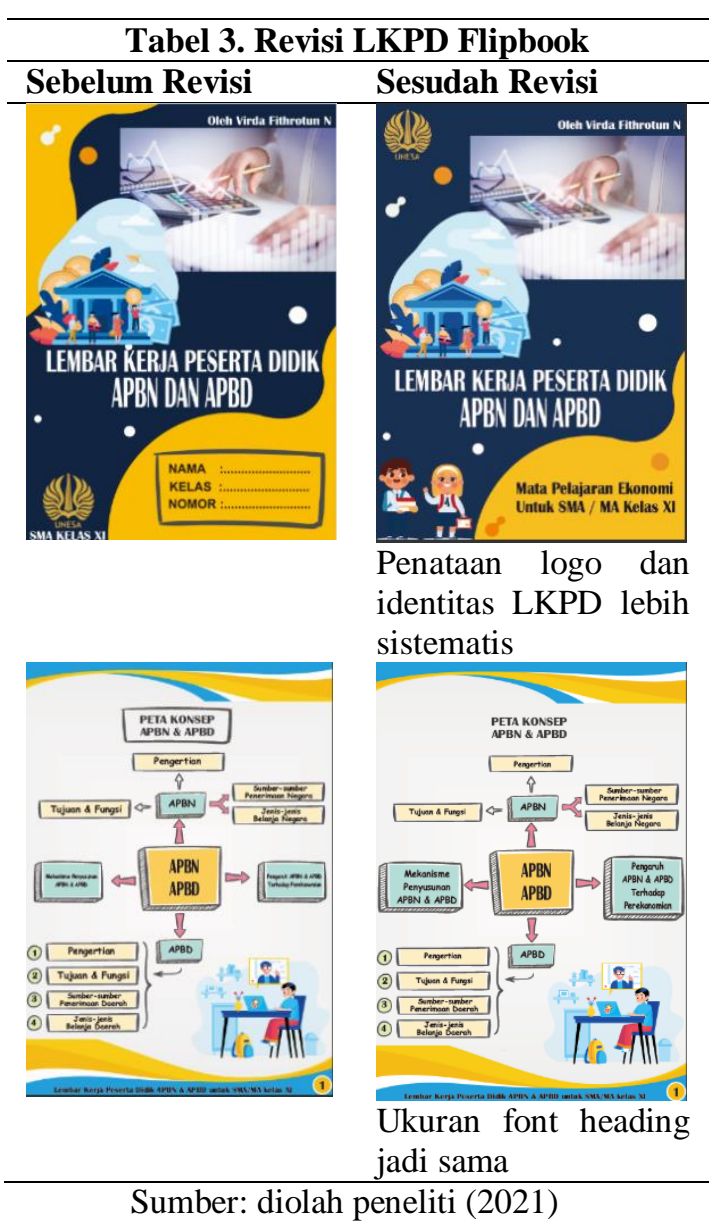

Tabel 3 menjabarkan bahwa terdapat beberapa penyempurnaan pada LKPD elektronik flipbook antara lain penyempurnaan pada penataan logo, penambahan gambar serta identitas yang jelas pada LKPD elektronik agar terlihat lebih sistematis. Selain itu perbaikan font yang berbeda ukuran pada setiap heading di peta konsep agar terlihat lebih tertata.
Setelah direvisi, LKPD elektronik akan divalidasi oleh para ahli. Berikut ini penjabaran data yang diperoleh dari hasil validasi:

\begin{tabular}{lll}
\hline & \multicolumn{2}{l}{ Tabel 4. Hasil Validasi } \\
\hline Aspek & \multicolumn{2}{l}{ Rata-Rata Hasil } \\
& Keseluruhan & \\
\hline Materi & $86,15 \%$ & Sangat Layak \\
Media & $85,71 \%$ & Sangat Layak \\
Evaluasi & $72,5 \%$ & Layak \\
$\bar{X}$ & $81,45 \%$ & Sangat Layak \\
\hline
\end{tabular}

Sumber: diolah peneliti (2021)

Tabel 4 adalah pencapaian dari hasil validasi produk. Validasi materi mendapatkan rata-rata yaitu sebesar $86,15 \%$ sehingga termasuk kategori sangat layak, validasi media mendapatkan rata-rata yaitu sebesar yaitu $85,71 \%$ masuk ke dalam kategori sangat layak, validasi evaluasi mendapatkan rata-rata yaitu sebesar $72,5 \%$ termasuk kategori layak, dan total rata-rata seluruh hasil validasi adalah $81,45 \%$ termasuk kriteria sangat layak.

Menurut hasil telaah yang diberikan oleh ahli materi, terdapat komentar untuk perbaikan yaitu materi APBN dan APBD yang terdapat di LKPD elektronik layak dan dapat digunakan sebagai Lembar Kerja Peserta Didik dalam pembelajaran ekonomi di sekolah dengan syarat penyempurnaan pada deskripsi materi alur mekanisme penyusunan APBN dan APBD agar lebih ringkas sehingga peserta didik mudah memahaminya.

Menurut hasil analisis materi diperoleh data yang didapatkan pada aspek kualitas isi dan tujuan ialah sebesar $80 \%$, pada aspek kualitas intruksional ialah sebesar $80 \%$, dan pada aspek kualitas bahasa ialah $100 \%$. Maka dapat disimpulkan jumlah rata-rata seluruh aspek yang didapat ialah sebesar $86,15 \%$ termasuk kriteria sangat layak. Maka dapat disimpulkan bahwa materi dalam LKPD elektronik sangat layak digunakan.

Menurut hasil telaah yang diberikan oleh ahli media terdapat komentar untuk penyempurnaan antara 
Jurnal PTK dan Pendidikan

Vol. 7, No. 1, Januari - Juni 2021 (27-35)

lain 1) penyesuaian font pada satu halaman harus konsisten agar lebih mudah terbaca, 2) pemilihan dan penempatan audio kurang sesuai, 3) penggunaan huruf besar dalam cover seperlunya, 4) LKPD belum memberikan instruksi dan variasi prosedur pengerjaan.

Menurut hasil analisis media diperoleh data pada aspek kualitas tampilan ialah sebesar $82,5 \%$, untuk aspek keterbacaan didapat sebesar $85 \%$, dan pada penyajian media $100 \%$. Maka dapat disimpulkan jumlah rata-rata seluruh aspek yang didapatkan ialah sebesar 85,71 termasuk kriteria sangat layak.

Menurut hasil telaah yang diberikan oleh ahli evaluasi maka terdapat komentar perbaikan antara lain 1) pembuatan soal kurang bervariasi jika ditinjau dari tingkat kemampuan berfikir yang sesuai tingkatan taksonomi bloom, 2) pembuatan soal kurang dalam menciptakan berfikir kritis peserta didik.

Menurut hasil analisis evaluasi yang didapatkan yaitu jumlah rata-rata seluruhnya ialah sebesar $72,5 \%$ termasuk kriteria layak. Maka dapat disimpulkan bahwa pembuatan soal pretest dan posttest dalam LKPD elektronik layak untuk dipakai.

Setelah hasil validasi materi, media, dan evaluasi termasuk ke dalam kategori layak, maka tahap selanjutnya adalah melaksanakan ujicoba produk. Pelaksanaan ujicoba produk ada dua tahap yaitu, sebelum dan sesudah mengenalkan LKPD elektronik kepada peserta didik. Di tahap sebelum menggunakan LKPD elektronik, peserta didik mengerjakan soal pretest. Berikut adalah data dari hasil pretest:

\begin{tabular}{ccl}
\hline & Tabel 5. Hasil Pretest \\
\hline Nilai & Frekuensi & Keterangan \\
\hline $0-10$ & 0 & Tidak Tuntas \\
$11-20$ & 0 & Tidak Tuntas \\
$21-30$ & 0 & Tidak Tuntas \\
$31-40$ & 1 & Tidak Tuntas \\
$41-50$ & 1 & Tidak Tuntas \\
$51-60$ & 4 & Tidak Tuntas \\
$61-70$ & 2 & Tidak Tuntas \\
$71-80$ & 7 & Tuntas
\end{tabular}

Virda Fithrotun Nufus, Norida Canda Sakti

\begin{tabular}{lll}
$81-90$ & 5 & Tuntas \\
$91-100$ & 0 & Tidak Tuntas \\
\% Ketuntasan & $\mathbf{6 0 \%}$ & Tidak Tuntas \\
\hline \multicolumn{2}{c}{ Sumber: }
\end{tabular}

Sumber: diolah peneliti (2021)

Tabel 5 memperlihatkan total peserta didik yang mencapai tuntas yaitu ada $60 \%$ atau sejumlah 12 orang, dengan pencapaian nilai terendah 40 dan pencapaian nilai tertinggi 90 .

Tahap selanjutnya yakni sesudah memakai LKPD elektronik. Pada tahap ini peneliti memerintahkan peserta didik untuk menjawab soal posttest yang sudah diberikan. Berikut merupakan pencapaian data dari hasil posttest:

\begin{tabular}{lll}
\hline \multicolumn{3}{c}{ Tabel 6. Hasil Posttest } \\
\hline Nilai & Frekuensi & Keterangan \\
\hline $0-10$ & 0 & Tidak Tuntas \\
$11-20$ & 0 & Tidak Tuntas \\
$21-30$ & 0 & Tidak Tuntas \\
$31-40$ & 0 & Tidak Tuntas \\
$41-50$ & 0 & Tidak Tuntas \\
$51-60$ & 1 & Tidak Tuntas \\
$61-70$ & 3 & Tidak Tuntas \\
$71-80$ & 2 & Tuntas \\
$81-90$ & 7 & Tuntas \\
$91-100$ & 7 & Tuntas \\
\% Ketuntasan & $\mathbf{8 0 \%}$ & Tuntas \\
\hline \multicolumn{3}{c}{ Sumber: diolah peneliti (2021) }
\end{tabular}

Tabel 6 dapat diketahui total peserta didik yang mencapai tuntas yaitu $80 \%$ atau sejumlah 16 orang dengan pencapaian nilai paling rendah 60 dan pencapaian nilai paling tinggi 100 .

Berdasarkan analisis data yang telah dilaksanakan, dapat diketahui soal yang paling banyak dijawab benar yaitu soal nomor 1 mengenai pengertian APBN sebesar $100 \%$ peserta didik. Sedangkan untuk soal yang paling banyak jawabannya salah yaitu soal nomor 10 mengenai fungsi APBD sebesar 40\% peserta didik menjawab salah. Hal itu disebabkan peserta didik belum memahami soal dan mudah terkecoh dengan jawabannya.

Setelah peserta didik selesai menjawab soal posttest, selanjutnya yaitu mengisi angket respon yang sudah disiapkan sesuai dengan ketertarikan atau minat peserta didik terhadap LKPD 
elektronik. Kemudian melakukan penganalisisan dari hasil angket respon yang sudah diisi oleh peserta didik. Pencapaian hasil respon peserta didik terdapat pada tabel di bawah ini:

\begin{tabular}{lll}
\hline \multicolumn{2}{c}{ Tabel 7. Hasil Respon Peserta Didik } \\
\hline Aspek & $\begin{array}{l}\text { Persentase } \\
(\%)\end{array}$ & Keterangan \\
\hline 1 & $95 \%$ & Sangat layak \\
2 & $100 \%$ & Sangat layak \\
3 & $100 \%$ & Sangat layak \\
4 & $100 \%$ & Sangat layak \\
5 & $100 \%$ & Sangat layak \\
6 & $90 \%$ & Sangat layak \\
7 & $80 \%$ & Layak \\
8 & $85 \%$ & Sangat layak \\
9 & $100 \%$ & Sangat layak \\
10 & $100 \%$ & Sangat layak \\
$\overline{\boldsymbol{X}}$ & $\mathbf{9 5 \%}$ & Sangat layak \\
\hline \multicolumn{4}{c}{ Sumber: diolah peneliti (2021) }
\end{tabular}

Dari tabel di atas, jumlah rata-rata dari seluruh hasil angket dari respon peserta didik kelas XI MIA 6 SMAN 2 Lamongan yaitu 95\% termasuk kriteria sangat layak. Jadi dapat disimpulkan respon peserta didik terhadap LKPD elektronik yakni sangat baik.

\section{Pembahasan}

\section{Kelayakan Lembar Kerja Peserta Didik Elektronik Berbasis Flipbook}

Kelayakan Lembar Kerja Peserta Didik elektronik berbasis flipbook bisa ditinjau dari perolehan hasil skor validasi materi, validasi media, serta validasi evaluasi. Rata-rata yang didapatkan dari validasi materi ialah sangat layak sebesar $86,15 \%$ yang menunjukkan bahwa penyajian materi telah sesuai dengan kompetensi dasar yang akan dicapai (Prastowo, 2015). Untuk rata-rata yang didapatkan dari validasi media ialah sebesar $85,71 \%$ termasuk kriteria sangat layak yang menunjukkan bahwa media flipbook telah sesuai dalam menyajikan gambar, audio, dan video. LKPD elektronik dilengkapi dengan ilustrasi yang mendukung materi pembelajaran dapat membantu peserta didik dalam menyerap dan memahami materi.
Sedangkan rata-rata validasi evaluasi ialah sebesar $72,5 \%$ termasuk kriteria layak yang telah menggunakan struktur kalimat pertanyaan yang baku, efektif dan konsisten. Hal ini sesuai dengan (Risandi, 2015) bahwa penggunaan LKPD elektronik dapat terbebas dari makna kalimat pertanyaan yang ganda apabila efektif dan sesuai dengan ejaan yang disempurnakan. Sehingga kesimpulan total rata-rata dari semua hasil validasi yang telah diperoleh yaitu sebesar $81,45 \%$ termasuk kriteria sangat layak. Hal ini dikarenakan Lembar Kerja Peserta Didik elektronik berbasis flipbook sudah sesuai dengan Badan Standar Nasional Pendidikan Vol. II/No. 1/Januari 2007 yang menjelaskan komponen buku teks pelajaran yang benar meliputi empat komponen, yaitu kelayakan isi, kebahasaan, penyajian dan kegrafikan.

Berdasarkan hasil analisis data yang didapat, total rata-rata validasi sebesar 81,45\%. Oleh karena itu kesimpulan yang diperoleh yaitu Lembar Kerja Peserta Didik elektronik berbasis flipbook pada mata pelajaran ekonomi kelas XI dinyatakan sangat layak digunakan.

\section{Kepraktisan Lembar Kerja Peserta Didik Elektronik Berbasis Flipbook}

Kepraktisan Lembar Kerja Peserta Didik elektronik dapat ditinjau lewat respon peserta didik. Hal ini bisa didapat lewat uijicoba produk ke 20 peserta didik kelas XI MIA 6 SMAN 2 Lamongan. Peserta didik diminta untuk mengamati Lembar Kerja Peserta Didik elektronik terlebih dahulu, selanjutnya peserta didik diberikan angket respon untuk diisi. Angket respon yang diberikan terkait dengan ketertarikan atau minat peserta didik pada LKPD elektronik.

Setelah itu hasil angket respon peserta didik dianalisis menurut skala guttman. Hasil jumlah rata-rata seluruhnya angket respon peserta didik ialah 95\% termasuk kriteria sangat layak. Maka disimpulkan respon peserta didik 
terhadap Lembar Kerja Peserta Didik elektronik yakni sangat baik.

Hasil dari respon peserta didik kelas XI MIA 6 SMAN 2 Lamongan menyatakan bahwa mereka memiliki ketertarikan serta termotivasi dalam proses pembelajaran, kegiatan belajar mengajar jadi tidak monoton, peserta didik juga berperan aktif dalam melaksanakan tanya jawab pada materi APBN dan APBD, dan materi jadi lebih mudah dipahami oleh peserta didik, dengan begitu hasil belajar akan meningkat.

Berdasarkan hasil analisis disimpulkan bahwa 1) perhatian peserta didik pada proses pembelajaran jadi lebih aktif, 2) peserta didik lebih semangat dan termotivasi dalam belajar, 3) pemahaman terhadap materi lebih mudah bagi peserta didik dalam belajar, sehingga hasil belajar dapat meningkat. Hal tersebut membuktikan bahwa pengembangan Lembar Kerja Peserta Didik elektronik berbasis flipbook yang telah dilakukan memiliki kriteria kepraktisan dengan interpretasi sangat layak.

Hal ini sama seperti pendapat yang dikemukakan dalam penelitian (Sutikno \& Isa, 2010) bahwa respon peserta didik yang menunjukkan positif dapat membuat peserta didik tertarik serta memiliki minat terhadap pengajaran yang dilakukan.

\section{Keefektifan Lembar Kerja Peserta Didik Elektronik Berbasis Flipbook}

Keefektifan Lembar Kerja Peserta Didik elektronik berbasis flipbook bisa ditinjau dari hasil belajar peserta didik. Kegiatan belajar mengajar dapat disebut efektif apabila peserta didik mencapai nilai ketuntasan klasikal sebesar $\geq 75 \%$ dari jumlah keseluruhan dengan nilai KBM sebesar $\geq 80$.

Pada saat peserta didik belum menggunakan Lembar Kerja Peserta Didik elektronik berbasis flipbook, peserta didik mengerjakan soal pretest yang telah diberikan. Dari hasil analisis data pretest dapat diperoleh sebesar $60 \%$ total peserta didik yang tuntas yaitu 12 orang. Pencapaian nilai terendah yaitu 40 dan pencapaian nilai tertinggi yaitu 90 .

Berdasarkan hasil analisis data posttest mengalami peningkatan menjadi $80 \%$. Hal ini sesuai dengan pernyataan (Hayati, 2015) yang menunjukkan bahwa hasil analisis media flipbook yang digunakan dapat meningkatkan hasil belajar peserta didik. Motivasi, aktivis, dan kreativitas peserta didik yang pembelajarannya menggunakan flipbook berpengaruh positif terhadap hasil belajar (Rasiman, 2014). Hal ini dikarenakan flipbook yang dirancang lebih interaktif dan menarik minat peserta didik. Sehingga LKPD elektronik flipbook yang dikembangkan efektif untuk meningkatkan pemahaman peserta didik.

Kesimpulannya yaitu Lembar Kerja Peserta Didik elektronik berbasis flipbook ialah efektif serta layak digunakan dalam kegiatan belajar. Ketuntasan ini membuktikan bahwa pengembangan Lembar Kerja Peserta Didik elektronik berbasis flipbook yang telah dilakukan bisa mendorong peserta didik dalam pemahaman materi APBN dan APBD dalam pembangunan ekonomi.

Hasil analisis di atas sependapat sama (Awalsyah et al., 2018) bahwa Lembar Kerja Peserta Didik yang diaplikasikan ke dalam flipbook efektif dalam pengajaran di kelas karena dapat membuat hasil belajar peserta didik mengalami peningkatan.

\section{PENUTUP}

Hasil yang diperoleh dari penelitian ini adalah 1) Kelayakan produk memperoleh rata-rata validitas sebesar $81,45 \%$ dengan kriteria sangat layak, 2) Kepraktisan produk memperoleh rata-rata sebesar 95\% dengan kriteria sangat layak, 3) Efektifitas produk memperoleh ratarata ketuntasan sebesar $80 \%$ dengan kriteria tuntas. Dengan demikian Lembar Kerja Peserta Didik elektronik berbasis flipbook layak, praktis, dan efektif untuk 
digunakan dalam meningkatkan hasil belajar peserta didik pada mata pelajaran ekonomi kelas XI. Dalam mengembangkan Lembar Kerja Peserta Didik elektronik berbasis flipbook perlu dilakukan inovasi dalam format bentuk offline. Agar peserta didik dapat menggunakan flipbook tanpa membutuhkan jaringan internet terlebih dahulu.

\section{DAFTAR PUSTAKA}

Asmi, R. ., Surbakti, D. N. ., \& Hudaidah. (2018). Pengembangan E-Modul Berbasis Flip Book Maker Materi Pendidikan Karakter untuk Pembelajaran Mata Kuliah Pancasila MPK Universitas Sriwijaya. Jurnal Pendidikan Ilmu Sosial, 27(1), 1-10.

Awalsyah, A., Sarwi, \& Sutikno. (2018). Pengembangan Lembar Kerja Siswa (LKS) Berbantuan Kvisoft Flipbook Maker untuk Mengembangkan Keterampilan Ilmiah Siswa. Unnes Physics Education Journal, 3(3), 7783.

Fitri, E. R. (2020). Pengembangan LKPD Berbantuan Kvisoft Flipbook Maker pada Mata Pelajaran Teknologi Perkantoran di SMKN 2 Nganjuk Pengembangan LKPD Berbantuan Kvisoft Flipbook Maker. 9, 281-291. Hayati, S. (2015). Pengembangan Media Pembelajaran Flipbook Fisika untuk Meningkatkan Hasil Belajar Peserta Didik. Prosiding Seminar Nasional Fisika, 4(2), 49-54.

Prastowo, A. (2015). Panduan Kreatif Membuat Bahan Ajar Inovatif: Menciptakan Metode Pembelajaran yang Menarik dan Menyenangkan. DIVA Press.

Rasiman. (2014). Efektivitas Resource Based Learning Berbantuan Flipbook Maker dalam Pembelajaran Matematika SMA. Jurnal Karya Pendidikan Matematika, 1(2), 34-41. Riduwan. (2018). Skala Pengukuran Variabel-variabel Penelitian.
Alfabeta.

Risandi, R. (2015). Respon siswa SMA Negeri Pontianak terhadap Lembar Kerja Siswa Berbasis Multimedia Sub Materi Invertebrata. Artikel Penelitian. Pontianak: FKIP Universitas Tanjungpura Pontianak. Riyanto, Amin, M., Suwono, H., \& Lestari, U. (2020). The new face of digital books in genetic learning: A preliminary development study for students' critical thinking. International Journal of Emerging Technologies in Learning, 15(10), 175-190.

https://doi.org/10.3991/ijet.v15i10.1 4321

Saputri, D., Irianto, S., \& Bintaro, T. Y. (2019). Pengembangan Lembar Kerja Peserta Didik (LKPD) Materi Jaring-Jaring Kubus dan Balok Berbasis Project Based Learning (PjBL). Jurnal Elementaria Edukasia, 2(2), 98-102.

Sulastri, Y. L., \& Hakim, L. L. (2014). Pembelajaran Berbasis Mobile. Jurnal Pengajaran Matematika Dan Ilmu Pengetahuan Alam, 19(2), 173. https://doi.org/10.18269/jpmipa.v19i 2.458

Sutikno, W., \& Isa, A. (2010). Keefektifan Pembelajaran Berbantuan Multimedia Menggunakan Metode Inkuiri Terbimbing untuk Meningkatkan Minat dan Pemahaman Siswa. Jurnal Pendidikan Fisika Indonesia, 58-62. Yulaika, N. F., Harti, \& Sakti, N. C. (2020). Pengembangan bahan ajar elektronik berbasis flip book untuk meningkatkan hasil belajar peserta didik. Jurnal Pendidikan Ekonomi, Manajemen Dan Keuangan, 4(1), 67-76. https://doi.org/10.26740/jpeka.v4n1. p67-76 